\title{
Identification of Triterpenes and $\beta$-sitosterol in the Bark of Plane Tree Extracts
}

\author{
Szabina Plánder ${ }^{1 *}$, Blanka Simon ${ }^{1}$, Szabolcs Béni² ${ }^{2}$ Ágnes Alberti², Ágnes Kéry², Edit Székely \\ 1 Department of Chemical and Environmental Process Engineering, Faculty of Chemical Technology and Biotechnology, \\ Budapest University of Technology and Economics, H-1111 Budapest, Múegyetem rakpart 3., Hungary \\ 2 Department of Pharmacognosy, Faculty of Pharmacy, Semmelweis University, H-1085 Budapest, Üllői út 26., Hungary \\ * Corresponding author, e-mail: p.szabina@gmail.com
}

Received: 18 July 2018, Accepted: 06December 2018, Published online: 27 March 2019

\begin{abstract}
Plane tree is planted as ornamental tree in urban areas. This tree naturally sheds its bark during the spring; however, the shed bark is commonly regarded as a waste material without any significant application.

On the other hand, the bark of plane tree may be an important source of industrially relevant compounds, most notably betulinic acid. In our study a Supercritical Fluid Ultra Performance Convergence Chromatography (UPC²) system coupled with Evaporative Light Scattering Detector (ELSD), along with conventional HPLC, GC-MS and NMR were successfully utilized to analyze triterpenes in the extracts from the bark of plane tree. We show that not only betulinic acid, but other important triterpenes: betulin, betulinic aldehyde and $\beta$-sitosterol are also present in the extract of the plane tree bark. Among these the main compound is betulinic acid, with up to an order of magnitude larger concentration than the other constituents. The applied extraction method has a significant role on the concentration of the different compounds in the extracts. Most notably, neat $\mathrm{scCO}_{2}$ is not suitable to extract the polar betulinic acid, however betulin and betulinic aldehyde can be extracted selectively.
\end{abstract}

Keywords

bark of plane tree, betulin derivates, $\beta$-sitosterol, UPC ${ }^{2}$, supercritical fluid chromatography

\section{Introduction}

Triterpenenoids are an important class of natural plant materials with many important biological effects [1]. They are promising in the treatment of certain types of cancer by the inhibition of the replication of cancer cells by affecting the S phase of DNA synthesis [2] and they often show high anti-inflammatory, antiviral and antioxidant activities. Among these compounds the lupine-type pentacyclic triterpenes, like betulin (3-lup-20(29)-ene-3 $\beta, 28$-diol), betulinic aldehyde and betulinic acid are particularly interesting [3] due to their anticancer [4], antiviral [5], antibacterial, anti-inflammatory, antimalarial, anthelmintic and antioxidant activities [6]. Betulinic and platonic acids may also be inhibitors of the Human Immuno Deficiency Virus (HIV), the well-known primary agent of acquired immunodefiency syndrome (AIDS) [7]. Betulin and its natural and synthetic derivatives act specifically on cancer cells with low cytotoxicity towards normal cells [8]. Betulin can easily be converted to betulinic acid [9], thus the extraction of both compounds is important for practical applications.
The main source of betulin and its derivates is still the birch bark [10]. However, betulin and betulin derivates are widely spread in the plants' kingdom. Especially the bark of different trees, including plane tree might be a practical source of betulin and its derivatives [10]. Plane tree is a decorative tree in the middle Europe, Asia and in the Mediterranean region of America. It is grown as an ornamental tree in parks and on the road sides, due to its excellent tolerance of urban conditions and to the poor soil conditions. The attractive feature is that plane tree sheds its bark during the spring, which is regularly regarded as a waste material or is used for decoration only.

Dávid [11] isolated first a triterpenoid compound from the bark of Platanus acerifolia (Aiton) Willd., which was named platanol. Bruckner et al. [12] proved that this compound was betulinic acid, which is expected to be the main triterpene compound of plane tree bark extract. Betulin, betulinic aldehyde and its acetate, sitosterol, betulinic and betulonic acid, platonic acid was isolated by Aplin et 
al. [13]. Furthermore, four new 2-styrylchromones were also isolated from the bark of Platanus acerifolia (Aiton) Willd. [14]. Rhourri-Frih et al. [15] made qualitative analysis of London plane tree bark, and detected betulinic acid, betulinic aldehyde and betulinic aldehyde acetate with LC-APPI-MS.

A few constituents of the bark of Platanus occidentalis L. were identified [12, 16, 17], which were triterpenes, fatty acids and sterols. Dimeric and oligomeric proanthocyanidins were also isolated from the bark of Platanus orientalis L. [18-20].

Only a few quantitative reports are available on the triterpene content of plane bark. Galgon et al. [21] determined 3.07-3.41\% betulinic acid using gas chromatography of a methanolic extract of plane bark. Jäger et al. [22] measured with GC-FID $2.44 \%$ betulinic acid, and only trace amounts of betulin, oleanolic acid and ursolic acid. Pinilla et al. [23] applied different extraction methods (solid-liquid extraction, ultrasound assisted extraction, pressurized liquid extraction, supercritical fluid extraction) to investigate the optimal solvent and conditions for the extraction of betulinic acid from plane tree bark. Higher betulinic acid concentrations were obtained by ethanolic extraction followed by a simple pre-fractionation (46.21\% betulinic acid in an extract with $5.31 \%$ extraction yield). Preliminary SFE experiments showed, that the highest betulinic acid concentration and the highest yield can be reached with high ethanol co-solvent concentration, in their case with $20 \%$ ethanol co-solvent results $18.30 \%$ betulinic acid in an extract with $4.34 \%$ extraction yield. Isolation methods of betulinic acid from the bark of Platanus acerifolia (Aiton) Willd. are described in different patents [24-27].

It was shown as well that the triterpene content can be measured using the capillary Supercritical Fluid Chromatography (SFC) method. Separation of triterpenic acids (betulinic, oleanolic, ursolic and polpunonic acid) was examined using SFC coupled to Flame Ionization Detector (SCF-FID), which was shown to be more effective method, than GC or LC methods [28].

SFC has several advantages compared to the conventional liquid and gas chromatography [29]. Supercritical carbon-dioxide has lower viscosity and higher diffusion rate (thus faster mass transfer) than the liquids. Carbondioxide is cheaper and environmentally friendlier than the organic solvents. SFC makes it possible to use considerably smaller amount of organic solvents than in the case of HPLC, as they are applied only as co-solvent, usually in 5 to 15 percent. The strength of the mobile phase can easily be tuned by changing the density of the $\mathrm{scCO}_{2}$ by adjusting the temperature and the pressure. Comparing with $\mathrm{GC}$, non-volatile compounds can be analyzed at low temperature $\left(40^{\circ} \mathrm{C}\right)$. However, capillary SFC has stability problems. In the modern SFC methods, often referred to as convergence chromatography or SFx chromatography as well, packed columns are used [30, 31].

We applied a modern, stable and reproducible SFC method to determine triterpenes from different extracts of Platanus acerifolia (Aiton) Willd. obtained with various solvents (by $\mathrm{scCO}_{2}$ and by traditional extraction techniques).

\section{Materials and methods \\ 2.1 Chemicals}

The solvents for extraction of plane tree bark and saponification were obtained from Molar Chemicals (Budapest, Hungary). Solvents for GC-MS analysis was bought from Reanal Private Ltd. (Budapest, Hungary).

Pyridine-d5 (Sigma Aldrich) was applied as NMR solvent. Silica gel 60 absorbent was obtained from Merck for isolation.

Standards: $\beta$-sitosterol ( $>95 \%$ ), betulin ( $>97 \%$ ), betulinic acid $(>97 \%)$ were ordered from Sigma-Aldrich, betulinic aldehyde (>95\%) was bought from Chemos $\mathrm{GmbH}$ (Regenstauf, Germany).

\subsection{Plant material}

The bark of Platanus acerifolia (Ait.) Willd. was used as raw material. The bark of plane tree was obtained from Egererdő Erdészeti PLC. (Eger, Hungary) and was stored in a dry, dark place. Samples from two types of trees were applied in this study. Sample 1 and Sample 2 were obtained from 63 and 85 years old trees, respectively. The samples were milled prior use.

\subsection{Extraction of raw materials}

Conventional Soxhlet extraction was performed with ethanol, acetone, isopropanol, ethyl acetate, $n$-hexane at ambient pressure in triplicates. $25 \mathrm{~g}$ of ground bark was placed into the thimble and $200 \mathrm{ml}$ of selected solvents were placed in a round bottom flask.

The bark of plane tree was extracted with supercritical carbon dioxide in a pilot plant extractor. $800 \mathrm{~g}$ of ground bark was measured into the extractor vessel. The details of the about the equipment are described elsewhere [32]. Extraction using neat carbon-dioxide was performed at $40{ }^{\circ} \mathrm{C}$, pressures of 300 bar and 450 bar, respectively. 
About $50 \mathrm{~kg} \mathrm{CO}_{2} / \mathrm{kg}$ dry material was flown through the extractor during each measurement. Extraction using $5 \%$ ethanol as entrainer was carried out at $40{ }^{\circ} \mathrm{C}$ and 300 bar. About $80 \mathrm{~kg} \mathrm{CO}_{2} / \mathrm{kg}$ dry material was applied during the extraction using ethanol entrainer.

\subsection{Isolation of betulinic aldehyde}

The isolation was carried out using conventional open column chromatography. The height of the glass column was $39 \mathrm{~cm}$, the diameter was $1 \mathrm{~cm}$. Silica gel 60 (particle size: 63-200 $\mu \mathrm{m}$ ) was applied as stationary phase. Samples were saponified according to [33], to eliminate the fatty acid contaminants. The unsaponifiable fraction of the hexane extract was dissolved in $\mathrm{CHCl}_{3}$ and adsorbed onto Silica gel, then the solvent was evaporated. This sample was loaded on the top of the column. The column was washed with mixtures containing different ratios of hexane and ethyl acetate, as described in the Table 1. At the beginning of the isolation $45 \times 5 \mathrm{ml}$, then $80 \times 2 \mathrm{ml}$ fractions were collected separately. Every fifth fractions were monitored by thin-layer chromatography (TLC) with the standards of betulin, betulinic acid and $\beta$-sitosterol. Presence of these compounds was confirmed in the plant extracts, however a large additional spot was also observed. This was later confirmed by NMR measurements to be betulinic aldehyde. If betulinic aldehyde was observed in the fraction, all the previous four fractions were also investigated. Thus, the fractions containing betulinic aldehyde were identified and collected for isolation.

TLC monitoring was performed on $10 \times 20 \mathrm{~cm}$ aluminium foil plates coated with $0.2 \mathrm{~mm}$ layers of silica gel $\left(\right.$ Kieselgel $60 \mathrm{~F}_{254}$ ). Hexane: ethyl acetate 3:1 (volume \%) was used as eluent. Visualization was performed with $0.5 \%$ cerium-sulphate solution in $0.1 \mathrm{M}$ sulfuric acid, heated at $120^{\circ} \mathrm{C}$ for $10 \mathrm{~min}$.

\subsection{NMR method}

All NMR experiments were carried out using a $600 \mathrm{MHz}$ Varian DDR NMR spectrometer equipped with a $5 \mathrm{~mm}$ Inverse-Detection Gradient (IDPFG) probe head. Standard pulse sequences and processing routines available in VnmrJ 3.2 A / Chempack 5.1 were used for structure identification. The probe temperature was maintained at 298 $\mathrm{K}$ and a standard $5 \mathrm{~mm}$ NMR tube (Wilmad 535-PP) was used. The provided amount of isolated compound was dissolved in a single ampule of pyridine-d5 and transferred to the NMR tube. The complete resonance assignment was performed using $1 \mathrm{H}, 13 \mathrm{C}$, APT, gCOSY, zTOCSY,
Table 1 Volume and the ratio of the eluent solvents

\begin{tabular}{lcc}
\hline \multirow{2}{*}{$\begin{array}{l}\text { volume of solvent } \\
(\mathrm{ml})\end{array}$} & \multicolumn{2}{c}{ volume ratio of the solvents } \\
\cline { 2 - 3 } 100 & hexane $(\%)$ & ethyl acetate $(\%)$ \\
50 & 100 & 0 \\
50 & 95 & 5 \\
25 & 90 & 10 \\
25 & 88 & 12 \\
25 & 86 & 14 \\
25 & 84 & 16 \\
85 & 82 & 18 \\
\hline
\end{tabular}

bashdNOESY, gHSQCTOCSY, gHSQCAD, gHMBCAD and the selective versions of gradient HSQCAD and HMBC spectra. Residual solvent signals served as referencing the $1 \mathrm{H}$ and $13 \mathrm{C}$ chemical shift scales: $7.22 \mathrm{ppm}$ for ${ }^{1} \mathrm{H}$ and $135.9 \mathrm{ppm}$ for ${ }^{13} \mathrm{C}$, respectively.

\subsection{HPLC}

Analysis was carried out by a Jasco system equipped with an ERC-3113 degasser, a Jasco LG-980-02 gradient unit, a PU 980 HPLC pump, a Rheodyne 7725i sample injector and a PU-975 UV detector. The stationary phase was Supelco Hypersil ODS $(150 \times 4.6 \mathrm{~mm} \times 5 \mu \mathrm{m}) \mathrm{C}-18$ column. Injection volume was $20 \mu \mathrm{l}$. Experiments were performed at $25{ }^{\circ} \mathrm{C}$. The mobile phase consisted of acetonitrile (A) and water with $0.2 \%$ acetic acid $(B)$, the following gradient elution program was applied: 0 min $80 \%$ $(\mathrm{V} / \mathrm{V}) \mathrm{A}, 6 \min 80 \%(\mathrm{~V} / \mathrm{V}) \mathrm{A}, 7 \min 90 \%(\mathrm{~V} / \mathrm{V}), 8 \mathrm{~min}$ $100 \%$ (V/V) A, $38 \mathrm{~min} 100 \%$ (V/V) A. The flow rate was $1 \mathrm{ml} / \mathrm{min}$. Detection was accomplished at $205 \mathrm{~nm}$. Data evaluation was performed using the Borwin 1.21 software.

The identification of the peaks was performed by comparing the retention times of the respective standard solutions and by standard addition as well. Concentrations of the compounds were calculated by a standard calibration curve.

\subsection{GC-MS}

GC-MS analysis was carried out by Agilent 6890 GC equipment. Analytical capillary column was Supelco SLB-5 ms $(30 \mathrm{~m} \times 0.25 \mathrm{~mm} \times 0.25 \mu \mathrm{m})$. The carrier gas was helium (> $99.99 \%$ ) at a constant flow rate of $1 \mathrm{ml} / \mathrm{min}$. The injection volume was $1 \mu \mathrm{l}$ in spitless mode. The temperature program was $120^{\circ} \mathrm{C}(1 \mathrm{~min}), 20{ }^{\circ} \mathrm{C} / \mathrm{min}$ to $270{ }^{\circ} \mathrm{C}(20 \mathrm{~min})$, $10{ }^{\circ} \mathrm{C} / \mathrm{min}$ to $300{ }^{\circ} \mathrm{C}(5 \mathrm{~min})$. Analysis time was $36.5 \mathrm{~min}$.

For GC-MS detection an Agilent 5973 equipment with a quadrupole analyzer and an electron ionization system with ionization energy of $70 \mathrm{eV}$ was used and the $\mathrm{m} / \mathrm{z}$ 
range of 41-500 was scanned. The observed compounds were identified by comparing their retention times and the mass spectra with those of commercial standards and NIST 05 spectral library.

\subsection{Supercritical Fluid Chromatography (SFC)}

The Waters Acquity Ultra Performance Convergence Chromatography ${ }^{\mathrm{TM}}\left(\mathrm{UPC}^{2}\right)$ system with Empower 2 software was used for the SFC measurements. A C18 analytical packed column was used $(150 \times 3 \mathrm{~mm} \times 1.8 \mu \mathrm{m})$ with an injection volume of 0.5 and $1 \mu$ l. Carbon-dioxide methanol mixture with the flow rate of $2 \mathrm{ml} / \mathrm{min}$ was used as the mobile phase in gradient mode as described in Table 2. The analytical conditions were: $40{ }^{\circ} \mathrm{C}$ temperature and $14 \mathrm{MPa}$ pressure. The detector was an Evaporative Light Scattering Detector (ELSD).

\section{Results and discussion}

\subsection{Identification of the compounds}

Four main triterpenoid components were identified in the extract of plane tree bark. Betulin, betulinic acid and $\beta$-sitosterol were identified by comparing their SFC, HPLC and GC-MS retention times to references and from the GC-MS spectra. HPLC and GC-MS were performed from saponified extracts, as fatty acids may interfere with the analysis. In the case of SFC the saponification step was not necessary. Betulinic aldehyde was isolated, and identified with GC-MS and NMR methods. Mass spectrum of betulinic aldehyde was not found either in the known literatures nor in the NIST 05 library, thus after the identification of betulinic aldehyde, standard sample was purchased from Chemos GmbH and the retention time and MS spectrum was compared to the isolated compound.

Isolation was carried out using conventional open column chromatography. Identification of the fractions was performed with TLC, which was suitable for a rapid qualitative analysis. According to the TLC the main constituent fraction was the $39-40^{\text {th }}$ separated fractions. In the $52^{\text {th }}$ separated fraction we could isolate pure $\beta$-sitosterol. The isolated compounds were verified also with HPLC and GC-MS.

Table 2 Ratio of the eluent solvents

\begin{tabular}{lcc}
\hline time $(\mathrm{min})$ & carbon dioxide $(\%)$ & methanol $(\%)$ \\
\hline 0 & 98 & 2 \\
4.5 & 85 & 15 \\
4.6 & 85 & 15 \\
5 & 80 & 20 \\
7 & 98 & 2 \\
\hline
\end{tabular}

Fig. 1 shows the GC-MS spectrum of betulinic aldehyde. It has to be noted that this spectrum is very similar to that of betulin, only intensities of the ions are different.

In order to confirm the assignment of betulinic aldehyde, NMR measurements were also carried out using the isolated fraction (Fig. 2). This supported our previous finding based on the retention times and the mass spectrum. The structure identification of this compound concluded to betulinic aldehyde using the recorded 1D and 2D NMR data. As the complete resonance assignment of betulinic acid is known from the literature [34], the NMR

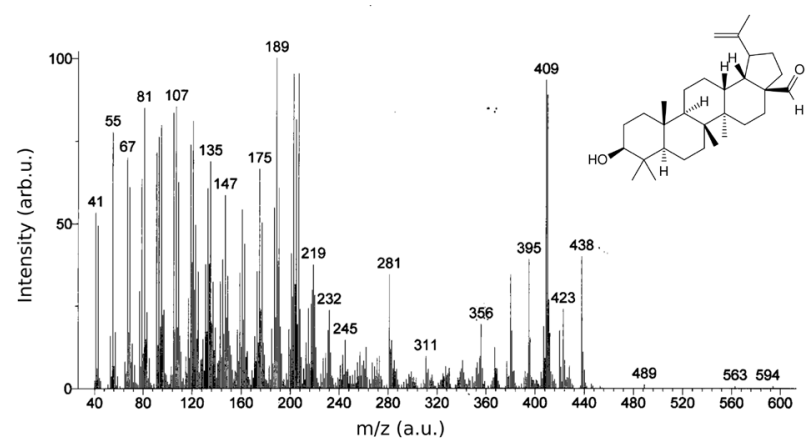

Fig. 1 MS spectra of betulinic aldehyde obtained after GC separation

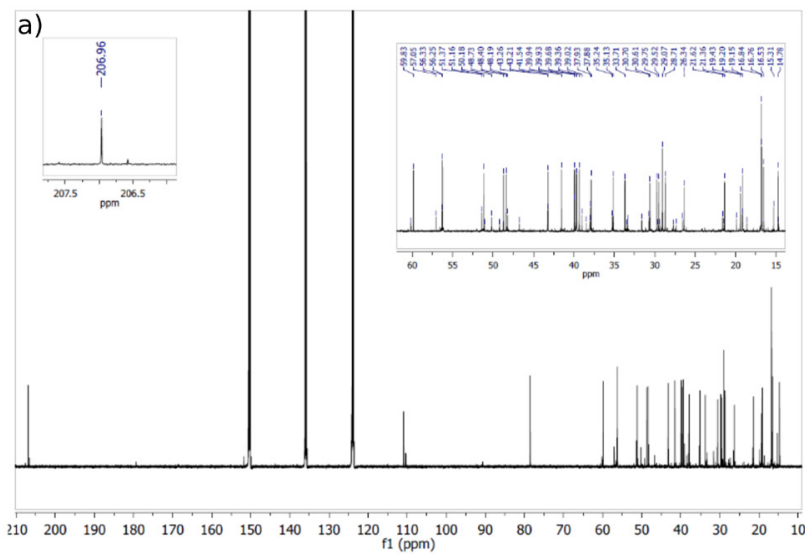

b)

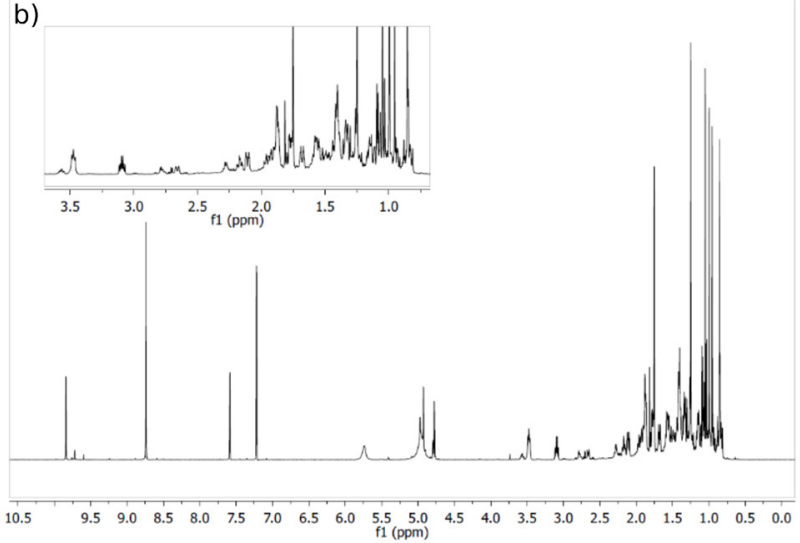

Fig. 2 The recorded ${ }^{13} \mathrm{C}$ (a) and ${ }^{1} \mathrm{H}$ NMR (b) spectra of betulinic aldehyde 
resonance assignment of betulinic acid served as a good entry to the appropriate aldehyde.

The applied HPLC method (with UV detection) was not sensitive enough to determine all the components quantitatively. Furthermore, betulin and its derivatives were not stable in the GC system. These findings showed that more advanced chemical analytical tools were necessary for the quantitative determination of the plane tree extract constituents. Therefore, we developed an SFC method using ELSD detection, which was not only faster, but the limit of quantification was also smaller than at the HPLC method and the conditions were also milder than in the case of the GC measurements.

Standard solutions of different concentrations (in the range of 0.025 to $0.500 \mathrm{mg} / \mathrm{ml}$ ) of each standard compound (betulin, betulinic aldehyde, betulinic acid and $\beta$-sitosterol) were prepared and injected, while subsequently the calibration curve was fitted based on the peak area and the injected concentration. The linear trendlines for each compound were then obtained using regression analysis and were applied to quantify the composition of the extracts. Fig. 3 shows the peaks of betulin, betulinic aldehyde, betulinic acid and $\beta$-sitosterol, obtained using SFC technique.

Fig. 4 shows the results of the quantitative analysis of the extracts.

In most of the cases the concentrations of betulin, betulinic aldehyde, $\beta$-sitosterol (Fig. 4) were about an order of magnitude smaller than that of the main component betulinic acid (Fig. 4) in the raw extracts except the pure $\mathrm{CO}_{2}$ extract.

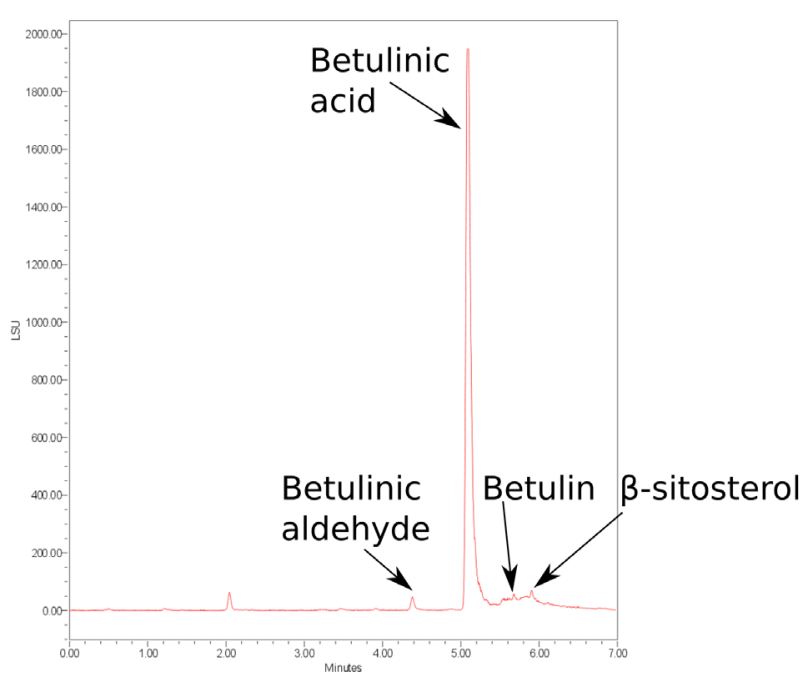

Fig. 3 SFC chromatogram of ethanol extract of plane bark
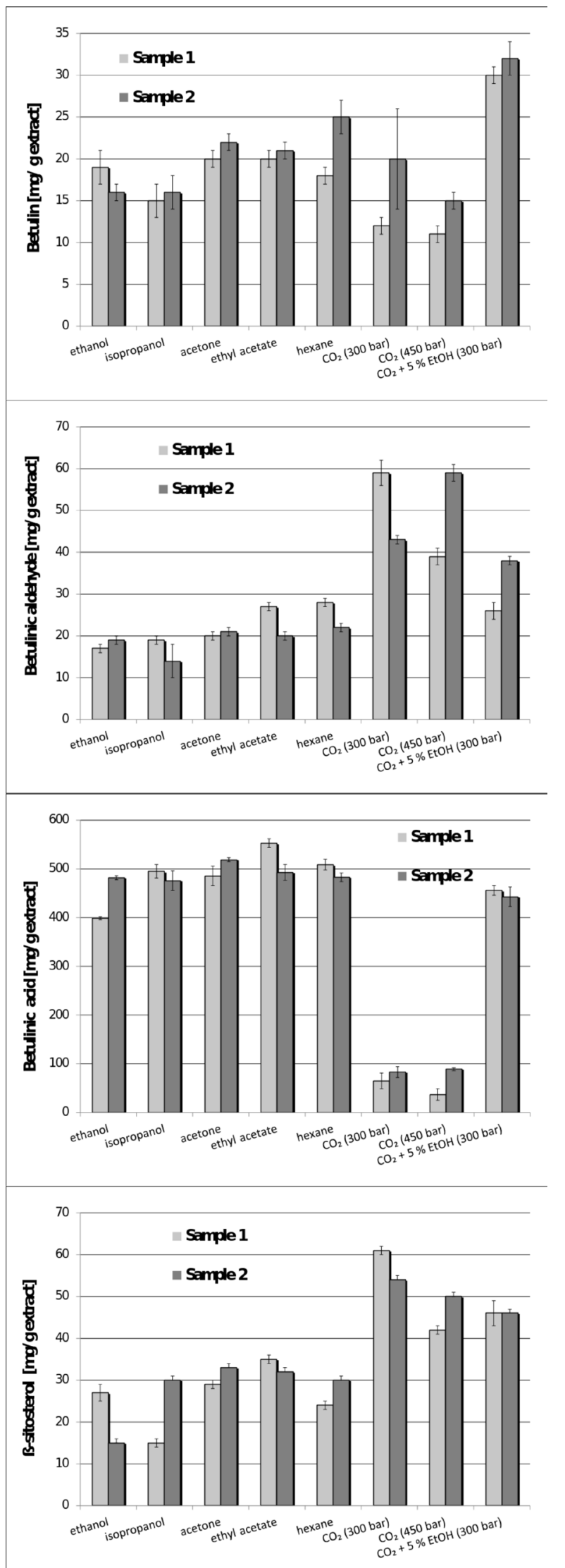

Fig. 4 Concentration of the examined compounds in the different extracts. 
Maximal betulin concentration was obtained with $\mathrm{scCO}_{2}$ solvent using $5 \%$ ethanol as entrainer, while all other polar and non-polar solvents yielded similar concentration of betulin in the extracts.

The betulinic aldehyde concentration was the highest in the case of extracts with supercritical carbon dioxide. Conventional solvents were effective to extract betulinic acid from plane bark independently of the polarity of the solvent.

While neat supercritical carbon dioxide was not a suitable solvent to get an extract with high betulinic acid concentration, addition of $5 \%$ ethanol entrainer resulted in similar betulinic acid concentration as the extracts obtained with conventional solvents.

Pinilla et al. [23] also found, that solid-liquid extraction using ethanol or ethyl acetate exhibits similar yield and concentration of betulinic acid. Our results show higher concentration and higher yield than in [17]. The reason may be the use of Soxhlet extraction, which was performed till the total depletion. On the other hand, in the case of supercritical fluid extraction our yields were smaller, but the concentration of betulinic acid in the extract was much higher, even without fractionation described in [17]. When $5 \%$ ethanol was used as entrainer, we obtained higher concentration, than in [17], where 10 or $20 \%$ of ethanol entrainer was applied.

Neat $\mathrm{scCO}_{2}$ was the best solvent to get high concentration of betulinic aldehyde, and at the same time the least effective solvent to reach high betulinic acid concentration. Addition of ethanol entrainer increased the betulinic acid concentration, but also led to the decrease of betulinic aldehyde concentration in the extract.

$\beta$-sitosterol was obtained in higher concentration using $\mathrm{scCO}_{2}$, than using organic solvents, which showed that supercritical fluid extraction is a suitable, environmental friendly technology to concentrate $\beta$-sitosterol.

Table 3 summarizes the yields of the studied compounds using different solvents. Deviation of the extraction yields is in the range of 0.01 to $0.31 \mathrm{~g} / 100 \mathrm{~g}$ dry material, while the deviation of the analytics method is in the range of 0.001 to $0.004 \mathrm{mg} / \mathrm{g}$ extract.

In agreement with the previous discussion in our paper, the betulinic acid yield was more than 10 times higher than that of the other investigated compounds. $\beta$-sitosterol was present in almost two times higher quantity than betulin and betulinic aldehyde, which were measured in the same quantity in the plant recovered with solvent extraction.

Ethanol, isopropanol, acetone and ethyl acetate were found to be more suitable solvents to obtain high yields
Table 3 Betulin, betulinic aldehyde, betulinic acid and ß-sitosterol recovery $[\mathrm{mg} / 100 \mathrm{~g}$ dry bark]

\begin{tabular}{|c|c|c|c|c|}
\hline & betulin & $\begin{array}{l}\text { betulinic } \\
\text { aldehyde }\end{array}$ & $\begin{array}{l}\text { betulinic } \\
\text { acid }\end{array}$ & ß-sitosterol \\
\hline Sample 1 & \multicolumn{4}{|c|}{ [mg /100 g dry material] } \\
\hline ethanol & 154 & 138 & 3244 & 220 \\
\hline isopropanol & 98 & 124 & 3232 & 98 \\
\hline acetone & 129 & 129 & 3144 & 188 \\
\hline ethyl acetate & 104 & 141 & 2881 & 182 \\
\hline hexane & 30 & 46 & 840 & 40 \\
\hline $\mathrm{CO}_{2}(300$ bar $)$ & 8 & 38 & 42 & 39 \\
\hline $\mathrm{CO}_{2}$ (450 bar) & 7 & 27 & 25 & 29 \\
\hline $\begin{array}{l}\mathrm{CO}_{2}+5 \% \\
\text { EtOH }(300 \text { bar })\end{array}$ & 48 & 42 & 730 & 74 \\
\hline \multicolumn{5}{|l|}{ Sample 2} \\
\hline ethanol & 134 & 159 & 4025 & 125 \\
\hline isopropanol & 108 & 95 & 3227 & 203 \\
\hline acetone & 143 & 137 & 3384 & 215 \\
\hline ethyl acetate & 117 & 111 & 2741 & 178 \\
\hline hexane & 43 & 38 & 826 & 51 \\
\hline $\mathrm{CO}_{2}$ (300 bar) & 11 & 23 & 44 & 29 \\
\hline $\mathrm{CO}_{2}$ (450 bar) & 8 & 32 & 49 & 28 \\
\hline $\begin{array}{l}\mathrm{CO}_{2}+5 \% \\
\mathrm{EtOH}(300 \text { bar })\end{array}$ & 48 & 57 & 665 & 69 \\
\hline
\end{tabular}

of betulin, betulinic aldehyde, betulinic acid, $\beta$-sitosterol than the nonpolar solvents (hexane, neat $\mathrm{CO}_{2}$ ). These latter two were not able to recover the targeted compounds. Although the extraction was more effective when ethanol entrainer was added to $\mathrm{scCO}_{2}$ compared to neat $\mathrm{scCO}_{2}$, previously mentioned organic polar solvents still resulted is much higher yields.

\section{Conclusion}

Triterpenes important for medicinal purposes can be extracted efficiently from the shed bark of plane tree using semipolar solvents. Supercritical fluid chromatography is an efficient tool in the qualification and quantification of these compounds. The method is fast and requires only the dissolution of the dry extract before the measurement in contrast with the previously published methodologies. In agreement with earlier investigations, betulinic acid was the major component, while betulin, betulinic aldehyde, and $\beta$-sitosterol were the minor components in the extracts. Betulinic aldehyde was identified and isolated from plane tree bark for the first time. Its presence was confirmed using NMR, HPLC and SFC techniques.

The extraction method plays a significant role on the final concentration of the triterpenes in the dry extracts. 
The mass fraction of betulin was small in all dry extracts. Thus the plane tree bark contains minor amounts of betulin, and it is not suitable as an industrial source of the compound. Meanwhile, the supercritical carbon dioxide extraction resulted smaller yield for all the main triterpenoid components than the organic solvents. This is attributed to the polarity of the molecules. In line, the less polar betulinic aldehyde and the $\beta$-sitosterol can be obtained in higher concentrations in the dry extracts obtained by the supercritical carbon dioxide.

\section{References}

[1] Dzubak, P., Hajduch, M., Vydra, D., Hustova, A., Kvasnica, M., Biedermann, D., Markova, L., Urban, M., Sarek, J. "Pharmacological activities of natural triterpenoids and their therapeutic implications", Natural Product Reports, 23(3), pp. 394-411, 2006. https://oi.org/10.1039/B515312N

[2] Amaral, L., Spengler, G., Molnar, J. "Identification of Important Compounds Isolated from Natural Sources that Have Activity Against Multidrug-resistant Cancer Cell Lines: Effects on Proliferation, Apoptotic Mechanism and the Efflux Pump Responsible for Multi-resistance Phenotype", Anticancer Research, 36(11), pp. 5665-5672, 2016.

https://doi.org/10.21873/anticanres.11149

[3] Shi, W., Tang, N., Yan, W. "Research and Development in Betulin and Betulinic Acid Derived Triterpenoids", Mini-Reviews in Organic Chemistry, 11(3), pp. 343-354, 2014. https://doi.org/10.2174/1570193X1103140915112124

[4] Zhang, D.-M., Xu, H.-G., Wang, L., Li, Y.-J., Sun, P.-H., Wu, X.-M., Wang, G.-J., Chen, W.-M., Ye, W.-C. "Betulinic Acid and its Derivatives as Potential Antitumor Agents", Medicinal Research Reviews, 35(6), pp. 1127-1155, 2015.

https://doi.org/10.1002/med.21353

[5] Xiao, S., Tian, Z., Wang, Y., Si, L., Zhang, L., Zhou, D. "Recent progress in the antiviral activity and mechanism study of pentacyclic triterpenoids and their derivatives", Medicinal Research Reviews, Special Issue: Special Issue dedicated to Professor Li-He Zhang, 38(3), pp. 951-976, 2018.

https://doi.org/10.1002/med.21484

[6] Yogeeswari, P., Sriram, D. "Betulinic Acid and Its Derivatives: A Review on their Biological Properties", Current Medicinal Chemistry, 12(6), pp. 657-666, 2005. https://doi.org/10.2174/0929867053202214

[7] Alakurtti, S., Mäkelä, T., Koskimies, S., Yli-Kauhaluoma, J. "Pharmacological properties of the ubiquitous natural product betulin", European Journal of Pharmaceutical Sciences, 29(1), pp. 1-13, 2006. https://doi.org/10.1016/j.ejps.2006.04.006

[8] Król, S. K., Kiełbus, M., Rivero-Müller, A., Stepulak, A. "Comprehensive Review on Betulin as a Potent Anticancer Agent", BioMed Research International, 2015, article ID: 584189, 2015. https://doi.org/10.1155/2015/584189

\section{Acknowledgement}

The authors highly appreciate the support of Prof. Béla Simándi during the research work. We thank Dr. Tamás Juhász and the Waters Hungary Kft. for the opportunity to work on the Waters Acquity UPC ${ }^{2}$ instrument.

This work is related to the Higher Education Excellence Program of the Ministry of Human Capacities in the frame of Biotechnology research area of Budapest University of Technology and Economics (BME FIKP-BIO). This project was also supported by the Bolyai János Research Scholarship of the Hungarian Academy of Sciences (S. Béni).

[9] Jung, M. E., Duclos, B. A. "Synthetic approach to analogues of betulinic acid", Tetrahedron, 62(40), pp. 9321-9334, 2006. https://doi.org/10.1016/j.tet.2006.07.023

[10] Hayek, E. W. H., Jordis, U., Moche, W., Sauter, F. "A bicentennial of betulin", Phytochemistry, 28(9), pp. 2229-2242, 1989. https://doi.org/10.1016/S0031-9422(00)97961-5

[11] Dávid, L. "A Platanus acerifolia leváló kéreghéjából izolált ismeretlen anyag vizsgálata" (A compound isolated from the bark of Platanus acerifolia), Magyar Gyógyszerészeti Társaság Értesítője, 20, pp. 8-12, 1944. (in Hungarian)

[12] Bruckner, V., Kovács, J., Koczka, I. "181. Occurrence of Betulinic Acid in the Bark of the Plane Tree", Journal of the Chemical Society, 0(0), pp. 948-951, 1948.

[13] Aplin, R. T., Halsall, T. G., Norin, T. "607. The chemistry of triterpenes and related compounds. Part XLIII. The constituents of the bark of Platanus $x$ hybrid Brot. and the structure of platanic acid", Journal of the Chemical Society, 0(0), pp. 3269-3273, 1963. https://doi.org/10.1039/JR9630003269

[14] Yang, C.-H., Yang, Y., Liu, J.-H. "Platachromone A-D: Cytotoxic 2-styrylchromones from the bark of Platanus $\times$ acerifolia (Aiton) Willd.", Phytochemistry Letters, 6(3), pp. 387-391, 2013. https://doi.org/10.1016/j.phytol.2013.05.003

[15] Rhourri-Frih, B., Chaimbault, P., Claude, B., Lamy, C., André, P., Lafosse, M. "Analysis of pentacyclic triterpenes by LC-MS. A comparative study between APCI and APPI", Journal of Mass Spectrometry, 44(1), pp. 71-80, 2009. https://doi.org/10.1002/jms.1472

[16] Thomas, A. F., Muller, J. M. "Some constituents of plane tree bark (Platanus occidentalis L.)", Society of Chemical Industry, 44, pp. 1794-1795, 1961.

[17] Yagishita, K., Iseda, S. "On the Triterpenic Acid of Platanus occidentalis LINN", Nippon Nōgeikagaku Kaishi, 29(12), pp. 964-967, 1955. https://doi.org/10.1271/nogeikagaku1924.29.964

[18] Nishanbaev, S. Z., Khidyrova, N. K., Kuliev, Z. A. "Dimeric Proanthocyanidins from Platanus orientalis Bark", Chemistry of Natural Compounds, 40(1), p. 93, 2004. https://doi.org/10.1023/B:CONC.0000025479.07578.5d

[19] Nishanbaev, S. Z., Kuliev, Z. A., Khidyrova, N. K., Vdovin, A. D., Abdullaev, N. D., Shakhidoyatov, K. M. "New Oligomeric Proanthocyanidins from Bark of Platanus orientalis", Chemistry of Natural Compounds, 41(4), pp. 404-409, 2005. https://doi.org/10.1007/s10600-005-0162-3 
[20] Nishanbaev, S. Z., Kuliev, Z. A., Khidyrova, N. K., Vdovin, A. D., Abdullaev, N. D., Shakhidoyatov, K. M., Aripov, O. A. "New oligomeric proanthocyanidin glycosides platanoside-A and platanoside-B from Platanus orientalis trunk bark", Chemistry of Natural Compounds, 46(3), pp. 357-362, 2010. https://doi.org/10.1007/s10600-010-9616-3

[21] Galgon, T., Höke, D., Dräger, B. "Identification and Quantification of Betulinic Acid", Phytochemical Analysis, 10(4), pp. 187-190, 1999.

https://doi.org/10.1002/(SICI)1099-1565(199907/08)10:4<187::AIDPCA443>3.0.CO;2-K

[22] Jäger, S., Trojan, H., Kopp, T., Laszczyk, M. N., Scheffler, A. "Pentacyclic Triterpene Distribution in Various Plants - Rich Sources for a New Group of Multi-Potent Plant Extracts", Molecules, 14(6), pp. 2016-2031, 2009. https://doi.org/10.3390/molecules14062016

[23] Pinilla, J. M., López-Padilla, A., Vicente, G., Fornari, T., Quintela, J. C., Reglero, G. "Recovery of betulinic acid from plane tree (Platanus acerifolia L.)", The Journal of Supercritical Fluids, 95, pp. 541-545, 2014.

https://doi.org/10.1016/j.supflu.2014.09.001

[24] Dräger, B., Neubert, R., Galgon, T., Wohlrab, W., Martin-LutherUniversität Halle-Wittenberg, "Herstellung von Betulinsäure" (Preparation of betulinic acid for use as anti-cancer and anti-HIV agent), Halle, Germany, DE19713768A1, 1998. (in German)

[25] Sauter, M., Boehringer Ingelheim Pharma GmbH and Co KG, "Process for Obtaining Betulinic Acid", Ingelheim, Germany, US6943260B2, 2005.

[26] Puder, C. H., Graef, H., Thumerer, M. J., Heitzmann, M., Boehringer Ingelheim Pharma Gmbh \& Co. Kg, "Verbessertes verfahren zur Gewinnung von Betulinsäure" (Improved Method for the Production of Betulinic Acid), Ingelheim, Germany, WO2007042542A1, 2007. (in German)
[27] Sauter, M., Boehringer Ingelheim Pharma Gmbh \& Co Kg, "Verbessertes verfahren zur Gewinnung von Betulinsäure" (Improved Method for Obtaining Betulinic Acid), Ingelheim, Germany, WO2003066659A2, 2003. (in German)

[28] Tavares, M. C. H., Vilegas, J. H. Y., Lanças, F. M. "Separation of underivatised triterpene acids by capillary supercritical fluid chromatography", Phytochemical Analysis, 12(2), pp. 134-137, 2001. https://doi.org/10.1002/pca.536

[29] Wang, Y. "Chapter 11 - Supercritical fluid chromatography of natural products", In: Webster, G. K. (ed.) Supercritical Fluid Chromatography: Advances and Applications in Pharmaceutical Analysis, 2nd ed., Pan Stanford Publishing, Singapore, Republic of Singapore, 2014, pp. 297-331. https://doi.org/10.4032/9789814463010

[30] Lesellier, E., West, C. "The many faces of packed column supercritical fluid chromatography - A critical review", Journal of Chromatography A, 1382, pp. 2-46, 2015. https://doi.org/10.1016/j.chroma.2014.12.083

[31] Gibitz Eisath, N., Sturm, S., Stuppner, H. "Supercritical Fluid Chromatography in Natural Product Analysis - An Update", Planta Medica, 84(6-7), pp. 361-371, 2018. https://doi.org/10.1055/s-0037-1599461

[32] Simándi, B., Deák, A., Rónyai, E., Yanxiang, G., Veress, T., Lemberkovics, É., Then, M., Sass-Kiss, Á., Vámos-Falusi, Z. "Supercritical Carbon Dioxide Extraction and Fractionation of Fennel Oil", Journal of Agricultural and Food Chemistry, 47(4), pp. 1635-1640, 1999. https://doi.org/10.1021/jf9809535

[33] Council of Europe "European Pharmacopoeia", 8th ed., Council of Europe, Strasbourg, France, 2014.

[34] Berger, S., Sicker, D. "Classics in Spectroscopy: Isolation and Structure Elucidation of Natural Products", 1st ed., John Wiley \& Sons, Weinheim, Germany, 2009. 